\title{
EVALUATION OF THE INSECTICIDAL EFFECTS OF HOT PEPPER (CAPSICUM FRUITECENT) AGAINST THE SURIVAL AND DISTRUCTIVENESS OF SITOPHILUS ZEAMAIS ON MAISE GRAINS.
}

\author{
${ }^{1}$ Egbo Walamam Mansi And Francis Inivie Ambrose ${ }^{2}$ \\ ${ }^{1}$ Department Of Science Laboratory Technology, Bayelsa State Polytechnic Aleibiri. .pm.b 168, Ekeremor \\ ${ }^{2}$ Department Of Agricultral Technology, Bayelsa State Polytechnic Aleibiri. Pm.b 168, Ekeremor \\ http://doi.org/10.35410/IJAEB.2019.4406
}

\begin{abstract}
The laboratory study on the effectiveness of hot pepper as protectant for maize against Sitophilus zeamaize was carried out. Different treatment concentration in (gram) of hot pepper was administer in three replicates for each pepper concentration on 20 seeds of Maize grains in 15 different plastic containers with lid. Twenty adult Sitophiluszeamaise pest were introduced into each of the experimental container and then screw closed with the container lid and then kept on laboratory shelves under ambient environmental condition for 24 days. The number of emergence holes on the maize grains, pest survival and mortality rate in each set upwereevaluated at the end of the study period (24, days). The results reveal that $30 \%$ of the pest died during the study period (24 days) in the hot pepper treatment concentration of $1 \mathrm{~g}$. $50 \%$ of the pest died in the hot pepper treatment concentration of $2 \mathrm{~g} .55 \%$ of pest died in the hot pepper treatment concentration of 3.5 , while $75 \%$ of the pest died in the treatment concentration of $6 \mathrm{~g}$ corresponding to the initial evaluation of the survival rate of the pest in question. Significance of theprotectant effect of the hot pepper treatment on maize grain against Sitophiluszeamaise attack was evaluated by analysis of variance. The analysis of variance indicated that treatment of maize grains with $1 \mathrm{~g}, 2 \mathrm{~g}, 3.5 \mathrm{~g}$ and $6 \mathrm{~g}$ of hot pepper shows very high significance difference at $(\mathrm{p}=-.001$ and 0.005). The study revealed that hot pepper was effective in protecting maize seed against the survival and the destructiveness of Sitophiluszeamaize The trend of the results indicate that the hot pepper protectant effect increase with concentration (gram).
\end{abstract}

Keywords: Assessment, survival, destructiveness, zeamais,grains.

\section{INTRODUCTION}

Global Food production is under serious threat as a result pest attack. About $35 \%$ on the field and $14 \%$ in storage approximately $50 \%$ in total crops are lost annually due to attack by insect and pest, which adversely affects the world food production during crop growth, harvest and storage (Jitendraet.al. 2009). Various methods have been adopted over the years to minimize food production losses due to insect attack. Some of the pest managementapproaches that have been conducted, include, chemical, biological, physical, and cultural methods. 
Maize is a principal cereal crop in the tropics and subtropics. The crop is said to have originated from central South America. Its botanical name is Zea- mays of the family graminaeand is mainly cultivated from the seed or grains. In Nigeria, maize is the third most important grain crop produced; only preceded by guinea corn and millet (Olufade, 1974). The crop grows best in low land, loamy fertile soil with $\mathrm{pH}$ range of $5.5-8.0$, warm temperature range of $21-27^{\circ} \mathrm{C}$ and an annual rainfall of $650-1,520 \mathrm{~mm}$ (Offoret al, 1998). Maize is grown as principal source of carbohydrate, but when eaten at the early stage can also provide a measure of certain vitamins like A and C (Anyanwuet al, 1989).

Maize is an important diet especially during the hunger season (Paladaet al, 1986). The grain can be eaten when the crop is still green. The grain is used industrially for the production of bread flour, in brewery, in corn flakes production, germ seed and source of corn oil. It also form basis of livestock feeds especially feed for monogastric animals.It is one of the most valuable and cheapest sources of carbohydrate feed for animas because of its digestibility and availability of its starch. The nutrient content of maize include, $70.79 \%$ starch, $9.69 \%$ protein and $4.42 \%$ oil but contributes $15.05-15.3 \%$ respectively of the total calories protein intake of cereal (National Agricultural Development Rep, 1971).

It is however unfortunate that in spite of the numerous importance of maize largely cultivated in this part of the continent; there is still acute shortage of maize grains to the next planting season and also for consumption during off season. One of the main causative factors attributable to shortage of maize gran is insect infestation.Pest infestation is not only restricted to the field but it continues even into the storage system. (Olufade, 1974). Adesuyi (1982) reported that insect most frequently found on stored maize are Sitophilus zeamais. Akinsami (1977) reportedthat this weevil is capable of consuming $30-50 \%$ of grains in storage room. The adult and larva causes considerable damages on maize resulting to characteristics holes and lose of weight. Moreover, severe insect infestation causes reduction of the food quality, low biochemical responses on the photosynthetic arial plant and also affects the germinating power of the grains.

Various chemical insecticides have been used to control this insect but excessive and indiscriminate use of chemical had led to serious social and environmental problems by poisoning of livestock's, fish, wildlife and other beneficial organisms. Researches have established that use of synthetic organic pesticides, particularly the chlorinated hydrocarbons cause serious pollution of environmental media (water, air and soil), thereby affecting human health and causing death of non-target organisms (animals, plants, and fish) (Biswaset.al. 2014). The use of synthetic chemicals have been restricted because of their carcinogenicity, teratogenicity accompanied with high and acute residual toxicity (Feng and Zheng, 2007; Pretty, 2009 ;Dubey et al, 2011 and Khatar, 2011)

In developing countries such as Nigeria, the limited knowledge of the application of insecticides hasincreased the population of the insect pest which has also resulted to the pest resistance against the insecticides due to over usage/dosage. Plant extracts and essential oils are safe, ecofriendly and more compatible with environmental components compared to synthetic pesticides. For instance, Neem seed oil is reported that it possess fungicidal, nematocidal and bactericidal properties (Schmutterer, 1995). (Mehihom, 2011) also reported that neem possess Molluscidal, 
diuretic and antiarthric properties. Plant extracts and essential oils use as crop protectant against insect attack are categories as green pesticides. There is an increasing trend in use of botanicals with more than 2400 bioactive plant species identified for their insecticidal and anti - pathogenic properties (Karunamoorthi, 2012).

In the course of trying to control grain pest, many natural insecticides have been proven to be more effective in the control of Sitophilus zeamais. For instance, in Malawi, wood ash, alkaline ash, pepper etc were used in protecting maize against the insect infestation. (Goloboet al, 1982).This paper in focused on the assessment of the use of hot pepper as insecticide against the survival and destructiveness on Maize grain by Sitophiluszeamais.

\section{MATERIALS AND METHODS}

\section{Maize grain.}

The maize grains used for the study was the local (white) variety. The maize (Zeamays) was bought from Agudama- Epie market in Yenagao Local Government Area of Bayelsa State. The maize grains were already physically infested with the test pest as at the time of collection for the study. The collected grains were then air dried to $15 \%$ moisture content.

\section{Test Organism}

The test organism (Sitophiluszeamays) was properly identified using the chart provided by the Natural Resource Institute (NRI)Central avenueChatan maritime kent MB4, 4TB United kingdom.Sitophiluszeamays used in the study were collected from infested maize grains bought from Odi town in Kolokuma Local Government Area of Bayelsa state. The maize grains were put in an airtight polythene bag and transported to the former Bayelsa state college of Arts and Science Agricultural Laboratory. The grains were sieved with a wire mesh basket in order to remove the grains powder formed. The test organisms were then handpicked from the sieved grains. The insects (test organism) were then cultured in fresh ventilated plastic jar containing stored maize for about seven daysbefore the commencement of the experiment

\section{Method.}

Twenty uninfected maize grains of about $7.2 \mathrm{~g}$ weight were counted and put into each of 15 different plastic containers labeled $A_{1}, A_{2}, A_{3}, B_{1}, B_{2}, B_{3}, C_{1}, C_{2}, C_{3}, D_{1}, D_{2}, D_{3}, F_{1}, F_{2}, F_{3}$. The pepper used as insecticide was weighed with Hause analytical balance.1g, of the dry pepper was put in three replicate into containers $\mathrm{A}_{1}, \mathrm{~A}_{2}$, and $\mathrm{A}_{3} .2 \mathrm{~g}$ of pepper was also put in thee replicate into container $\mathrm{B}_{1}, \mathrm{~B}_{2}$, and $\mathrm{B}_{3} .3 .5 \mathrm{~g}$ was put in three replicate into containers $\mathrm{C}_{1}, \mathrm{C}_{2}$, and $\mathrm{C}_{3}$ while $6 \mathrm{~g}$ grams of pepper was added in three replicate into containers $\mathrm{D}_{1}, \mathrm{D}_{2}$, and $\mathrm{D}_{3}$.. No pepper was added to the maize content of containers $\mathrm{F}_{1}, \mathrm{~F}_{2}$, and $\mathrm{F}_{3}$ respectively as they were kept as control. Set ups.Twenty adultsof Sitophilus zeamais were introduced into each of the experimental and control containers. The containers were screwed with their cover. They were then kept in the laboratory shelves under ambient environmental condition for 24days.

Number of emergence holes was used as the destructive index. The number of holes was counted and analysis of variance was used to find the significance of the insecticidal potential of the 
treatment, while least significant difference was used to indicate the different levels significance. The survived weevils were counted to determine the

death and survival rate of the insect pests in each treatment concentrations of the pepper. The counts for survived rate was taken weekly while the count for the destructive index ie. The number of holes were counted at the end of the 24 day

\section{Data analysis}

1) 1 Analysis of variance (ANOVA) test was conducted to determinethe insecticidal effect of the pepper treatment as maize grain protectant against Sitophilus zeamaise.

C.F $=\frac{G^{2}}{N}$

where $\mathrm{N}=\mathrm{D} . \mathrm{F}(\mathrm{t})(\mathrm{r})=15, \mathrm{t}(5)=$ number of treatments and $\mathrm{r}(3)=$ number replicate for treatment concentration

$\mathrm{TSS}=\sum X^{2}-\mathrm{C} . \mathrm{F}$

$\mathrm{T}_{\mathrm{r}} \mathrm{SS}=\frac{\Sigma T^{\mathrm{I}}}{r}$

E.SS $=\mathrm{TSS}-\mathrm{T}_{\mathrm{r}} \mathrm{SS}$

D. $F\left(T_{r}\right)=t-1$ ie $(5-1)=4$

Error $=\mathrm{t}(\mathrm{r}-1)=5(3-1)=5 \times 2=10$

Total D.F $=(\mathrm{r})(\mathrm{t})-1=3 \times 5-1=14$

$\mathrm{T}_{\text {r. }} \mathrm{MS}=\frac{T r S S}{D . F T r}=\frac{T r S S}{t-1}$

$\mathrm{EMS}=\frac{E S S}{t(r-1)}$

Computed $\mathrm{F}=\frac{T r, M S}{E S S}$

C.F $=$ Corrected factor

$\mathrm{G}=$ Grand total

SS $=$ Sum of square

$\mathrm{T}_{\mathrm{r}} \mathrm{SS}=$ Treatment sum of squares

T.SS $=$ Total sum of squares 
D.F $=$ Degree of freedom

E.SS $=$ Error sum of squares.

TMS $=$ Treatment means of square.

EMS $=$ Error means of square.

2) Analysis of the effectiveness of hot pepper treatment on the mortality rate of the Sitophilus zeamaise pests was conducted using equation (11). This analysis is useful in determining which of the pepper treatment concentration was more effective as insecticide against the targeted pest.

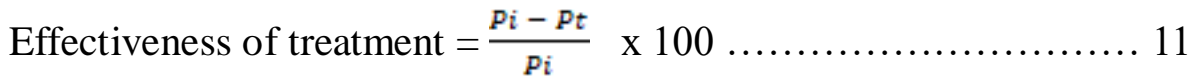

Where $\mathrm{P}_{\mathrm{i}}$ is initial population of Sitophilus Zeamaise at time zero.

$\mathrm{P}_{\mathrm{t}}$ is the population of Sitophilus Zeamaise at time $\mathrm{t}$ (end of experiment)

\section{RESULTS AND DISCUSSIONS}

\section{Results}

Table1: Mean value of the survived Sitophilus zeamais population in hot pepper treated maize grains

\begin{tabular}{|l|l|l|l|l|l|}
\hline \multirow{2}{*}{$\begin{array}{l}\text { Treatment } \\
\text { concentration } \\
(\mathrm{g})\end{array}$} & \multicolumn{2}{|l|}{ NO of Replicates } & \multirow{2}{*}{ Total } & Mean \\
\cline { 2 - 5 } & 1 & 2 & 3 & & \\
\hline 0 & 20 & 20 & 20 & 60 & 20 \\
\hline 1 & 14 & 14 & 14 & 42 & 14 \\
\hline 2 & 9 & 11 & 10 & 30 & 10 \\
\hline 3.5 & 9 & 10 & 8 & 27 & 9 \\
\hline 6 & 6 & 5 & 4 & 15 & 5 \\
\hline
\end{tabular}


Table 2: Mortality rate of Sitophilus zeamais in hot pepper treated maize grains.

\begin{tabular}{|l|l|l|}
\hline Treatment concentration $(\mathrm{g})$ & Total death & Mortality rate (\%) \\
\hline 0 & 0 & 0 \\
\hline 1 & 18 & 30 \\
\hline 2 & 30 & 50 \\
\hline 3.5 & 33 & 55 \\
\hline 6 & 45 & 75 \\
\hline
\end{tabular}

Table 3: Showing the effectiveness of the hot pepper against the destructiveness of the Sitophilus zeamais

\begin{tabular}{|l|l|l|l|l|l|}
\hline \multirow{2}{*}{$\begin{array}{l}\text { Treatment } \\
\text { concentration } \\
(\mathrm{g})\end{array}$} & \multicolumn{2}{l|}{ NO of Replicates } & Total & Mean \\
\cline { 2 - 5 } & 1 & 2 & 3 & & \\
\hline 0 & 200 & 203 & 195 & 598 & 199.33 \\
\hline 1 & 60 & 89 & 75 & 224 & 74.87 \\
\hline 2 & 44 & 66 & 60 & 170 & 56.67 \\
\hline 3.5 & 20 & 15 & 17 & 52 & 17.33 \\
\hline 6 & 18 & 4 & 7 & 29 & 9.67 \\
\hline
\end{tabular}

Table 4: Results of statistical parameters evaluation

\begin{tabular}{|l|l|}
\hline Parameters & Values \\
\hline C.F & $\mathbf{2 0 1 8 . 4}$ \\
\hline G $^{2}$ & $\mathbf{3 0 2 7 6}$ \\
\hline$T_{\mathrm{r} S S}$ & $\mathbf{3 8 7 . 6}$ \\
\hline T.SS & $\mathbf{3 9 3 . 6}$ \\
\hline D.F & $\mathbf{1 4}$ \\
\hline
\end{tabular}




\begin{tabular}{|l|l|}
\hline E.SS & $\mathbf{6}$ \\
\hline TMS & $\mathbf{9 6 . 9}$ \\
\hline EMS & $\mathbf{0 . 6}$ \\
\hline F & $\mathbf{1 6 1 . 5}$ \\
\hline
\end{tabular}

Table 5: Analysis of variance of survived Sitophilus zeamais population in hot pepper treatment

\begin{tabular}{|l|l|l|l|l|l|l|}
\hline $\begin{array}{l}\text { Sources of } \\
\text { varaiation }\end{array}$ & $\begin{array}{l}\text { Degree of } \\
\text { Freedom } \\
\text { (D.F) }\end{array}$ & SS & MS & $\begin{array}{l}\text { Computed } \\
\text { F }\end{array}$ & $\begin{array}{l}\text { Tabulated F } \\
1 \%\end{array}$ & $\begin{array}{l}\text { Tabulated F } \\
5 \%\end{array}$ \\
\hline Treatment & 4 & 387.6 & 96.9 & 161.5 & 3.32 & 2.37 \\
\hline Error & 10 & 6 & 0.6 & & & \\
\hline Total & 14 & 393.6 & & & & \\
\hline
\end{tabular}

From the analysis of variance $\mathrm{F}_{\text {cal }}=161.5$ while the $\mathrm{F}$ tabulated $\mathrm{F}_{\text {crit }}=3.34$.

Results of analysis of the Effectiveness of pepper treatment on the death rate of Sitophilus zeamais

$$
\begin{aligned}
& \text { Pepper treatment concentration of } 1 \mathrm{~g} \text { was }=\frac{20-14}{20} \times 100=30 \% \\
& \text { Pepper treatment concentration of } 2 \mathrm{~g} \text { was } \frac{20-10}{20} \times 100=50 \% \\
& \text { Pepper treatment concentration of } 2 \mathrm{~g} \text { was } \frac{20-9}{20} \times 100=55 \% \\
& \text { Pepper treatment concentration of } 2 \mathrm{~g} \text { was } \frac{20-5}{20} \times 100=75 \%
\end{aligned}
$$

\section{DISCUSSION}

Sitophiluszeamais attack is one of the most serious pest problems that maizefarmers contend with annually. This insect pest causes loss of maize grain nutrient and value during storage The insecticidal effects of hot pepper on Sitophiluszeamais in stored maize grain were investigated. The destructiveness of the maize grain by the pest, the mortality rate and the survival rate of the pest on treatment of the stored grain with hot pepper at different concentration were 
evaluated.The results of the survival rate of the Sitophiluszeamaispest in each pepper treatment concentration during the 24 days period of the experimentation is shown in Table 1 . The results show that the entire pest survived in the experimental replicates without the pepper treatment. In the experimental replicates with $1 \mathrm{~g}$ hot pepper treatment, there was an average population survival of 14 representing $70 \%$. In the experiments with $2 \mathrm{~g}$ hot pepper treatment, the average population of the pest (Sitophilus zeamais) that survived is 10 representing $50 \%$, in the experiment replicates with $3.5 \mathrm{~g}$ hot pepper concentration, average population of the pest survival is 9 representing $45 \%$. The least survival rate was observed in experimental replicates containing hot pepper concentration of $6 \mathrm{~g}$. Here the average pest survival population was 5 representing only $25 \%$. Table 2 shows the results of the evaluation of the average mortality rate of the pest in each of the pepper treatment concentration. The results reveal that $30 \%$ of the pest died during the study period ( 24 days) in the hot pepper treatment concentration of $1 \mathrm{~g} .50 \%$ of the pest died in the hot pepper treatment concentration of $2 \mathrm{~g}$. $55 \%$ of pest died in the hot pepper treatment concentration of 3.5 , while $75 \%$ of the pest died in the treatment concentration of $6 \mathrm{~g}$ corresponding to the initial evaluation of the survival rate of the pest in question. Analysis of variance in table 5 show that the F calculated 393.6 and Fcrit was 3.34 indicating that the hot pepper was significantly effective in reducing the population of the maize grain pest (Sitophiluszeamais) within 24 days.(Al-Mazraawi and Ateyyat, 2009; Ateyyatet.al. 2009), conducted research on the botanical insecticidal potency of Thymus vulgaris, Allium cepa, Allium sativum, Saturejahortensis, Achilleabiebersteinii, Cinnamomumverum, Syzygiumaromaticum, extracts against B. tabacihaveand reported60-100\% mortality rate. (Mohantyet.al. 1995) reported the effectiveness of neem seed kernel extract against diamond back moth (Plutellaxylostella), tomato fruit borer (Helicoverpaarmigera), brinjal fruit borer (Leucinodesorbonalis)) and serpentine leaf miner (Liriomyzatrifollii). (Chanda (2011) reported $60-83 \%$, repelling and larvicidal effects ofT. triquetrum, against human blood suckingleech, U. crinita, 77-90 \%, and B. multiplex 60- $93 \%$ effectiveness respectively.Dimetry, 2012). Reported the insecticidal effects of neem seed oil on pest and fungi. The result of the analysis of variance aspresented in Table 5, indicate that the hot pepper treatment has significant insecticidal effect on Sitophiluszeamais $(p \leq 0.5)$

\section{CONCLUSION AND RECOMMENDATION}

Insect pest infestation is a serious threat to food production all over the world. How the effect of this menace is more pronounce in Africa as result of none or poor access to more than food preservation technology. Many farmers depend on synthetic chemical pesticides to protect their agricultural products. However, synthetic chemical pesticides have potential and significant environment effect hence their uses is been restricted. Botanical pesticides are better alternative to synthetic chemical pesticides, as the are eco -friendly, effective, readily available and cheaper. Many natural products and essential oils from natural products have been proven to have efficient insecticidal effects on crops pest. In this paper, the effectiveness of hot pepper as insecticidal protectant of Zeamaise grain against Sitophiluszeamais destructiveness has been reported.

It is recommended that local farmers should be made known the effectiveness of hot pepper in protecting their stored produce (maize) and should be encouraged to apply the techniques.More 
research on Hot pepper insecticidal properties and other natural products should be promoted. Farmers should be train on modern application techniques of pesticides.

\section{REFERENCES}

Adesuyi S.A. (1982). Field Trials with permethrin Dust for the Control of Insect Infestation onStored Maize in Southern Nigeria. Journa 1 of Stored product Research vol2 :(3)

Akinsanmi, A. (1977). Secondary Agricultural Science Longman.Pp 245.

Al-Mazraawi M.S. and Ateyyat M. (2009) Insecticidal and repellent activities of medicinal plant extracts against the sweet potato whitefly, Bemisiatabaci(Hom.:Aleyrodidae) and its parasitoidEretmocerus mundus (Hym.: Aphelinidae). journal of Pest Science. 82(2):149154.

Ateyyat M.A., Al-Mazraawi M.S., Abu-Rjai T. and Shatnawi M.A. (2009) Aqueous extracts of some medicinal plants are as toxic as imidacloprid to the sweet potato whitefly, Bemisiatabaci. Journal of Insect Science.9(15).

Biswas S.K., Rahman S., Kobir S.M.A., Ferdous T. and Banu N.A. (2014) A Review on Impact of Agrochemicals on Human Health and Environment: Bangladesh Perspective. Plant Environment Development, Vol3(2):31-35.

ChandaVongsombath (2011). Botanical Repellents and Pesticides Traditionally Used against Haematomagous invertebrate in Loa DPR. M.Sc. Dissertation submitted to the faculty of Science and Technology, Acta University Uppsala.

Dubey, N.K., Shukla, R., Kuman, A., Singh, P and Prakash, B (2011).Global Scenario on theapplication of Natural products in integrated Pest Management. Dubey, N.K, CAB Oxfordshire. UK. Pp. 1-20

Feng, W Zheng, X .(2007). Essential Oils to control Almaria alternate in vitro and in vivo. Food control Vol 18: 1126 - 1130.

Jitendra K., Nitin K. and Kulkarni D.K. (2009) Plant-based pesticides for control of HelicoverpaamigeraonCucumis.Asian Agric. History.Vol 13(4):327-332.

Karunamoorthi K. (2012) Medicinal and Aromatic Plants: A Major Source of Green Pesticides/ Risk-Reduced Pesticides. Med Aromatic Plants vol 1:137.

Khatar , H.F (2011). EcosmartBiorational insecticides. Alternative Insect control Strategies in Insecticides Perveen. F(Ed) InTech, Kijeka Croatia. ISBN 979-953-307-667; 5

Mehihom, H., Al-Rasheid, K.S AND Abdel-Ghaffer, F. (2011). The Neem Tree Story: Extracts that really work in Nature help. Parasitology Research Monographs / Mehihom, H (Ed). Springer-Verag, Berlin. Pp 77-108Offor, U.S and Ansa, J.E.O. (1998).Tropical Crop Husbandry Area Corps.Pp 5-9 
Olufade A (1974) Nigerian Journal of entomology, Vol 1: 57 - 62

Palada M.C., Vogel W.O., Mareck J.H (1986) IITA Res Briefs 7 No 4.

Pretty, J.(2009). The pesticide Detox towards a more sustainable Agriculture. Earth Scan, London.

SezanurRahman., Sudhangshu Kumar Biswas.,Nirmal Chandra Barman., TamannaFerdous

(2016). Plant Extract as Selective Pesticide for Integrated Pest Management.Biotechnological.Research.Journal. Vol 2(1):6-10 